Pesq. Vet. Bras. 36(10):1005-1008, outubro 2016 DOI: 10.1590/S0100-736X2016001000014

\title{
Ulcerative and granulomatous enteritis associated with Molineus torulosus parasitism in neotropical primates ${ }^{1}$
}

\author{
Max Bruno Magno Bacalhao ${ }^{2}$, Raul Antunes Silva Siqueira ${ }^{3}$, Tiago Ferreira Lopes Nery ${ }^{4}$, \\ Millena de Oliveira Firmino ${ }^{3}$, Temístocles Soares de Oliveira Neto ${ }^{5}$, Harlan Hallamys \\ Lima Nascimento ${ }^{2}$, Ricardo Romão Guerra ${ }^{5}$ and Ricardo Barbosa Lucena ${ }^{5 *}$
}

\begin{abstract}
Bacalhao M.B.M., Siqueira R.A.S., Nery T.F.L., Firmino M.O., Oliveira Neto T.S., Nascimento H.H.L., Guerra R.R. \& Lucena R.B. 2016. Ulcerative and granulomatous enteritis associated with Molineus torulosus parasitism in neotropical primates. Pesquisa Veterinária Brasileira 36(10):1005-1008. Programa de Pós-Graduação em Ciência Animal, Universidade Federal da Paraíba, Centro Ciências Agrárias, Cidade Universitária, Areia, PB 58397-110, Brazil. E-mail: lucena.rb@gmail.com

This paper reports eleven cases of ulcerative and granulomatous enteritis associated with Molineus torulosus parasitism in different species of neotropical primates of the Sapajus genus. All of the affected monkeys had been apprehended by the environmental police and were being treated in a rehabilitation center for wild animals. The clinical history was weight loss and debility. During the necropsy, several nodules were found on the duodenum and proximal jejunum wall, with ulcers on the adjacent intestinal mucosa, including the nodules in the pancreas of four monkeys. Histologically, eosinophilic granulomas were observed in the small intestine, associated with fibrosis, eggs and adult models of Trichostrongylidae, etiology consistent with Molineus torulosus. This study describes the first cases of parasitism in Sapajus flavius, a species previously considered extinct, but recently rediscovered, and presents the occurrence of M. torulosus in two other species, Sapajus libidinosus and Sapajus apella.
\end{abstract}

INDEX TERMS: Enteritis, parasitism, Molineus torulosus, neotropical primates, Sapajus flavius, new world monkeys, parasite, pathology.

RESUMO.- [Enterite ulcerativa e granulomatosa com parasitismo de Molineus torulosus em primatas neotropicais.] São relatados 11 casos de enterite ulcerativa e granulomatosa associada ao parasitismo por Molineus torulosus em diferentes espécies de primatas neotropicais do gênero Sapajus. Todos os macacos afetados haviam sido apreendidos pela polícia ambiental e estavam sendo tratados em um centro de reabilitação de animais silvestres. 0

\footnotetext{
${ }^{1}$ Received on June 12. 2015.

Accepted for publication on July 29, 2016.

Part of the MS Dissertation of the first author.

${ }^{2}$ Programa de Pós-Graduação em Ciência Animal, Universidade Federal da Paraíba, Centro de Ciências Agrárias, Cidade Universitária, Areia, PB 58397-000, Brazil.

${ }^{3}$ Graduação em Medicina Veterinária, UFPB/CCA, Areia, PB. 58397-000, Brazil.

${ }^{4}$ Parque Zoobotânico Arruda Câmara, Avenida Gouveia Nóbrega, Centro, João Pessoa, PB 58020-325, Brazil.

${ }^{5}$ Departamento de Ciências Veterinárias, Universidade Federal da Paraíba, Centro de Ciências Agrárias, Cidade Universitária, Areia, PB 58397000, Brazil. *Corresponding author: lucena.rb@gmail.com
}

histórico clínico era de emagrecimento e debilidade. Durante a necropsia, foram constatados diversos nódulos na parede do duodeno e jejuno proximal, com úlceras na mucosa intestinal adjacente, além de nódulos no pâncreas de quatro macacos. Histologicamente, observou-se no intestino delgado, granulomas eosinofílicos associados à fibrose, ovos e exemplares adultos de tricostrongilídeos, etiologia consistente com Molineus torulosus. O presente trabalho descreve os primeiros casos de parasitismo em Sapajus flavius, uma espécie antes considerada extinta e recentemente redescoberta, e relata a ocorrência de $M$. torulosus em outras duas espécies, Sapajus libidinosus e Sapajus apella.

TERMOS DE INDEXAÇ̃̃O: Enterite, parasitismo, Molineus torulosus, primatas neotropicais, Sapajus flavius, macacos do Novo Mundo, parasita, patologia.

\section{INTRODUCTION}

The genus Sapajus comprehends neotropical primates, from the Cebidae family, subdivided into different species, 
found in a large portion of the Brazilian territory (Lynch Alfaro et al. 2012). Some species of primates of this genus are included on the list of the critically threatened of extinction (INCN 2012), such as the case of the Macgrave's capuchin monkey (Sapajus flavius), a species endemic of Northeast Brazil, for a long time considered extinct and recently rediscovered in parts of the Atlantic Rainforest (Oliveira \& Langguth 2006).

Knowledge of the helminthic fauna pertinent to the Brazilian neotropical primates, including the Sapajus genus, is insufficient. Few studies refer to the description of parasites in the wild New World primates (Toft 1982), and studies that correlate the parasitism with the clinical and pathological aspects in these animals are even more rare (Strait et al. 2012). The parasite Molineus torulosus (Nematoda, Trichostrongylidae) has been described in neotropical primates, such as Sapajus apella (previously Cebus apella), Aotus sp. and Saimiri sp., in some areas of South America (McClure \& Chandler 1982, Toft 1982, Durette-Desset et al. 2001), but there are still few descriptions of this parasite in primates in Brazil (Miguel et al. 2013). To the authors' knowledge, there is no description of this parasitism in Sapajus libidinosus. As a result of the few models of wild Sapajus flavius or kept in captivity, there is no description of the occurrence of the parasites in this species.

The present study has the purpose of describing the occurrence of $M$. torulosus in different species of primates of the Sapajus genus kept in a center of rehabilitation in the northeast of Brazil, including the first description of this parasite in S. flavius and S. libidinosus, and evaluating the clinical and pathological aspects associated to the infection by this parasite.

\section{MATERIALS AND METHODS}

Eleven capuchin monkeys with nodules in the intestinal serosa were identified in a study involving 20 necropsies of capuchins of three different species, performed in the Histology Laboratory and Veterinary Pathology of the Universidade Federal da Paraíba. The capuchin monkeys with intestinal lesions were classified and identified as four of the Sapajus flavius species, five S. libidinosus and two $S$. apella, originated from a center for rehabilitation of wild animals in the State of Paraíba, northeast of Brazil (CETAS/ PB). The monkeys were seized from illegal trafficking in the metropolitan area of João Pessoa.

The primates were submitted to necropsy after natural death, after a history of progressive weight loss and weakness. A complete necropsy was performed on all the animals. All of the lesions and fragments of all the internal organs were identified and described, including samples of skin and brain, and then they were placed in $10 \%$ neutral buffered formalin. The sample was embedded in paraffin, sectioned at $3 \mu \mathrm{m}$-thicknesses and stained with haematoxylin and eosin (HE). The histopathological lesions were described, including a detailed identification and a description of the structures of the parasites associated with the lesion.

\section{RESULTS}

The necropsy findings on all of the primates included emaciation and multiple grayish-tan nodules of $0.5-2 \mathrm{~cm}$ in diameter, at times coalescent, forming masses in the small intestine serosa, predominately duodenum, the first third of the jejunum, and also in the pancreas of four primates (Fig.1A). Some nodules were noted in the intestinal mucosa and submucosa, with contiguity to the intestine's lumen in the form of ulcers of up to $5 \mathrm{~mm}$ in diameter, covered with fibrin and hemorrhage. In the cut, the nodules presented thick and firm walls, with a necrotic friable center, at times mineralized. In two cases it was possible to observe the presence of numerous adult worms, with approximately $1 \mathrm{~cm}$ in length. The mesenteric lymph nodes were enlarged and reddish. Microscopic examination of the small intestine revealed markedly expansion and compression of the tunica muscularis and elevation of the overlying serosa in the granulomas. The granulomas are composed of numerous epithelioid macrophages, eosinophils, degenerate and viable neutrophils surrounding multiple cross and tangential sections of adult nematodes and eggs (Fig.1B,C). The granulomas are surrounded by a discontinuous fibrous capsule which is subtended by numerous lymphocytes and plasma cells. Multifocally, there are bands of collagen throughout the granuloma. The nematodes are up to $120 \mu \mathrm{m}$; have a $5 \mu \mathrm{m}$ thick cuticle with evenly spaced longitudinal cuticular ridges; a pseudocoelom; platymyarian/coelomyarian musculature; and a prominent digestive tract lined by few multinucleate cells with a low brush border. Eggs are 30-50 $\mu \mathrm{m}$ in diameter and thin shelled. Previously described inflammatory cells extend into the overlying serosa and superficial submucosa and mildly expand the lamina propria (Fig.1D). Ulcerated areas of the intestine contained numerous viable and degenerate polymorphs and granulation tissue. The small intestine of all monkeys showed deep ulcers, accompanied with extensive areas of necrosis, involving all coats, including the serosa (Fig.1C,D). Diffusely, there is mild follicular hyperplasia of the gut-associated lymphoid tissue. In two monkeys, the large mesenteric blood vessels and vessels at the periphery of the granulomas were infiltrated by some worms and Molineus eggs. In the pancreas of the four hosts, neutrophilic and lymphocytic periductal pancreatitis with intraductal nematodes and eggs were observed, associated with mild desquamation of epithelium. Five hosts also had mild, subacute lymphoplasmacytic mesenteric lymphadenitis. Invasion of the host's vascular system (mesenteric) induced fibrin thrombi associated with $\mathrm{Mo}$ lineus eggs.

In the other evaluated organs, no lesions associated with Molineus eggs parasitism were observed. Other intercurrent lesions included traumatic lacerations on the skin, pneumonia, pleuritis and pulmonary abscess.

\section{DISCUSSION}

To the authors' knowledge, this manuscript described the first cases of the parasitism by Molineus torulosus in blond capuchin (Sapajus flavius). A species of non-human neotropical primates until recently considered extinct in nature, rediscovered and currently included in the red list of the species with high risk of extinction (INCN 2012). Although the primates of the present study presented other intercurrent lesions, non-related to the parasitism by M. torulosus, the high parasitic infestation, associated to severe ulcers 

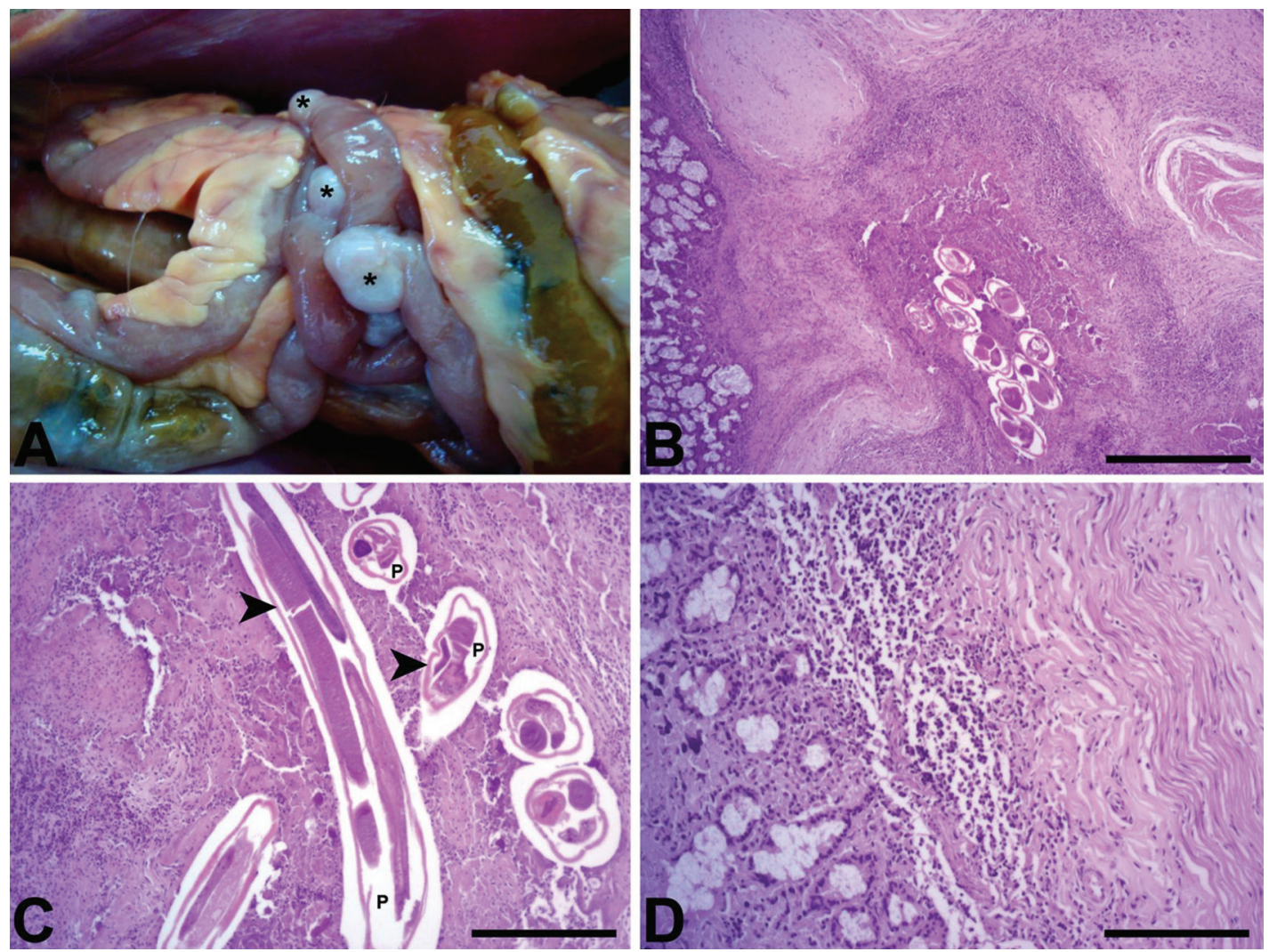

Fig.1. Photographic image and photomicrographies of small intestine of capuchin monkeys (Sapajus sp.). (A) Several nodular formations in serosa of capuchin monkey (S. flavius) infected with Molineus torulosus (asterisks). (B) Transmural granuloma associated with adult trichostrongylids and eggs, etiology consistent with $M$. torulosus, in S. libidinosus. Sections of nematodes are surrounded by cellular debris, many viable and degenerate inflammatory cells and further surrounded by a thick fibrous capsule. HE, Bar=100 $\mu$ m. (C) Nematodes are surrounded by necrotic cells. Note the external cuticular ridges (arrowheads) and pseudocoelom (P). Hematoxylin and eosin, Bar=50 $\mathrm{m}$. (D) The lamina propria and superficial submucosa are expanded by inflammatory cells, composed of epithelioid macrophages, lymphocytes and eosinophils. HE, Bar $=100 \mu \mathrm{m}$.

in the small intestine certainly contributed to stress, weight loss and cachexia, resulting in severe debilitation The knowledge of any illness that affects animals threatened by extinction is fundamental so that the programs of rehabilitation and conservation of the species can succeed. Nematode morphology, size, tissue location, and host, in the present case, were consistent with an identification key of M. torulosus (Durette-Desset et al. 2001).

M. torulosusis a small parasite from the Secernentea class, Strongylida order and Trichostrongylidae suborder, that affects the upper digestive system, including pylorus, the small intestine and occasionally the pancreas, but it never affects the terminal portion of the jejunum or the ileum (Toft 1982). In the present study, the pancreatic lesions were moderate or discrete from subacute to chronic in character. However the intestinal lesions were severe, characterized by accentuated inflammation, ulceration and hemorrhage. Different from the lesions caused by other Trichostrongylus that basically resulted in peeling and subsequently inflammation of the gastrointestinal epithelium, parasitism by $M$. torulosus in primates causes profound lesions on the intestinal wall, resulting in the perforation of the epithelium, as well as of the mucosae and muscularis mucosae (Brack et al. 1973). The cycle of life of these parasites is still not fully known. It is known that the infecti- ve larvae (L3) penetrates the epithelium and burrows into the submucosa, with subsequent larvae maturation, and then deposits eggs, causing the formation of the submucosal granulomas. The eggs are expelled through channels from the granuloma into the intestinal lumen. Invasion of the host's vascular system results in the formation of fibrin thrombus. Alternatively, the extraintestinal migration by the hematogenous route (via portal vein) or by direct tissue penetration has, as consequence, chronic pancreatitis. Due to the major severity of the lesions when compared to the parasitism by other trichostrongylus, the capuchin monkeys possibly represent unnatural hosts of M. torulosus (Brack et al. 1973). In our study, the lesions had similar severity in different species of capuchin evaluated, suggesting that Sapajus genus presents similar susceptibility to the infection by M. torulosus.

\section{CONCLUSIONS}

This study represents the first description of the parasitism of Molineus torulosus in blond monkeys and demonstrates that the infection by parasite can causes severe debility in these primates, compromising their quality of life and predisposition to the infection by other pathogens.

Consequently, the parasitism by M. torulosussis has to be considered and investigated in Sapajus sp. with a his- 
tory of progressive weight loss and debility, since different species of primates of this genus show similar signs and lesions as caused by this parasite.

\section{REFERENCES}

Brack M., Myers B.J \& Kuntz R.E. 1973. Pathogenic properties of Molineus torulosus in capuchin monkeys, Cebus apella. Lab. Anim. Sci. 23:360-365.

Durette-Desset M.C., Fribourg Blanc L.A. \& Vuong P.N. 2001. Molineus torulosus (Nematoda, Trichostrongylina, Molineoidea) a parasite of neotropical primates: New morphological and histological data. Parasite 8:53-60.

INCN 2012. Red List of Threatened Species. International Union for Conservation of Nature. Retrieved Dec. 20, 2013.

Lynch Alfaro J.W., Boubli J.P., Olson L.E., Di Fiore A., Wilson B., Gutiérrez-Espeleta G.A., Chiou K.L., Schulte M., Neitzel S., Ross V., Schwochow D., Nguyen M.T.T, Faria I., Janson C.H. \& Alfaro M.E. 2012. Explosive Pleisto- cene range expansion leads to widespread Amazonian sympatry between robust and gracile capuchin monkeys. J. Biogeogr. 39:272-288.

McClure H.M. \& Chandler F.W. 1982. A survey of pancreatic lesions in nonhuman primates. Vet. Pathol. 19:193-209.

Miguel M.P., Duarte S.C., Santos A.S., Matos M.P.C. \& Souza M.A. 2013. Mortality of Cebus apella by Molineus torulosus Parasitism in Midwestern Brazil. Acta Scient. Vet. 41:1-4.

Oliveira M.M. \& Langguth A. 2006. Rediscovery of Marcgrave's Capuchin Monkey and Designation of a Neotype for Símia flavia Schreber, 1774 (Primates, Cebidae). Bolm Mus. Nac. Zool. 523:1-16.

Strait K., Else J.G. \& Eberhard Mark L. 2012. Parasitic Diseases of Nonhuman Primates, p.197-297. In: Abee C.R., Mansfield K., Tardif S. \& Morris T. (Eds), Nonhuman Primates in Biomedical Research: diseases. Vol.2. 2nd ed. Academic Press, San Diego.

Toft II J.D. 1982. The pathoparasitology of the alimentary tract and pancreas of nonhuman primates: a review. Vet. Pathol. 19:44-92. 